\title{
Prevalence and epidemiological and histopathological features of canine cutaneous mast cell tumours in Uberlândia, Brazil
}

\author{
Marcelo Carrijo Costa ${ }^{2}$, Ana Letícia Daher Aprígio Silva ${ }^{1}$, Thais Almeida Moreira ${ }^{1}$, \\ Lígia Fernandes Gundim ${ }^{1}$, Alessandra Aparecida Medeiros-Ronchi ${ }^{1}$
}

Federal University of Uberlândia, ${ }^{1}$ Animal Pathology Laboratory, ${ }^{2}$ Animal Surgery, Uberlândia, Brazil

Received March 17, 2016

Accepted May 31, 2017

\begin{abstract}
This study aimed to perform a retrospective survey of canine cutaneous mast cell tumours at the Veterinary Hospital of the Federal University of Uberlândia, as well as to gather epidemiological data, such as breed, age, sex, and location. We also sought to histopathologically classify and characterize the mast cell tumours. Mast cell tumour was the most common neoplasm, accounting for $16.78 \%$ of skin neoplasms. In terms of the epidemiological data, the mast cell tumours did not show sexual predilection. Animals aged 9 to 12 years were the most affected $(44.14 \%)$. The genitalia were the most frequent location $(28.15 \%)$, and mongrel dogs showed the highest prevalence $(30.43 \%)$, followed by boxers $(22.61 \%)$. A total of 92 slides were classified; grade II was most frequently seen $(61.96 \%)$. Statistically, injuries such as necrosis, oedema, and haemorrhage were not related with histological classification $(P>0.05)$. Finally, the mitotic index was related to tumour grade $(P<0.05)$, and can act as an instrument for histological classification of these tumours. Mast cell tumour is the most common neoplasm in dogs, with no sex predilection. Contrary to what was expected, oedema, necrosis and haemorrhage do not increase according to graduation and can be seen in all classifications. Mitotic index is the best indicator to classify these neoplasms.
\end{abstract}

Skin cancer, dogs, mastocytoma

The incidence of neoplasms in dogs has increased considerably due to longer survival rates, better qualities of life, better nutrition, and vaccines and treatment for diseases that previously had been fatal (Giorgi 2012). Mast cell tumour is one of the most frequent skin cancers in dogs, accounting for $22.4 \%$ of these tumours (Meirelles et al. 2010). It occurs mainly in middle-aged dogs (ages 8-9 years), but there have been reports in dogs from ages 4 months to 19 years (Thamm and Vail 2008). The most frequently affected breeds are boxers, Boston terriers, bull terriers, and Labrador retrievers (Goldschmidt and Hendrick 2002).

The molecular and genetic events that culminate in the development of canine cutaneous mast cell tumours are still unknown, but some hypotheses have associated these tumours with chronic inflammation, genetic alterations, and viral infection (Daleck et al. 2009).

Macroscopically, the nodules are solitary, but may present as multiple skin lesions, varying in size from a few millimeters to several centimeters (Gross et al. 2005). For triage, one can use cytopathology analysis, which displays round cells with eccentric nuclei, granules in the cytoplasm, and anisocytosis and anisokaryosis that vary according to the level of differentiation. Eosinophils can be viewed between the neoplastic cells (Denicola 2009); however, histopathological and gradation analyses are necessary for the final diagnosis and the prognosis.

Canine mast cells tumour classification by Patnaik et al. (1987) and Kiupel et al. (2011) can be used, however, correlation between Kiupel low and high grade with prognosis has not been established (Childress et al. 2015). Patnaik's classification (Patnaik et al. 1987), which has been in use the longest, classifies neoplasms into 3 grades: grade I 
(well-differentiated mast cells in the dermis, with obvious granules and arranged in a line); grade II (moderately differentiated mast cells, with less clear granules and infiltration into the dermis and the subcutaneous layer); and grade III (poorly differentiated cells, with marked pleomorphism, rare granules, and a high mitotic index).

The present study was a retrospective survey of mast cell tumour cases treated at the Veterinary Hospital of the Federal University of Uberlandia, Minas Gerais, Brazil, between January 2002 and December 2012. We sought to evaluate epidemiological data, such as breed, sex, and location, as well as to further classify and characterize mast cell tumours histopathologically.

\section{Materials and Methods}

A retrospective study was carried out between 2002 to 2012, examining neoplasms in dogs with a subsequent focus on dogs with cutaneous mast cell tumours. Sex, breed, animal age, and tumour location were collected from 124 chip files, and a slide was selected for each animal. The regions were grouped into head, fore- and hind-limbs, genitals, tail, abdomen, thorax, inguinal, flank and back, and other (when present in areas not indicated above).

Table 1. Canine cutaneous neoplasms diagnosed at the Animal Pathology Laboratory, Federal University of Uberlândia (2002-2012).

\begin{tabular}{|c|c|c|}
\hline Neoplasm & Number & Percentage (\%) \\
\hline \multicolumn{3}{|l|}{ Benign } \\
\hline Haemangioma & 38 & 5.14 \\
\hline Lypoma & 37 & 5.01 \\
\hline Sebaceous adenoma & 22 & 2.98 \\
\hline Fibroma & 21 & 2.84 \\
\hline Papilloma & 17 & 2.30 \\
\hline Trichoblastoma & 17 & 2.30 \\
\hline Hepatoid gland adenoma & 9 & 1.22 \\
\hline Sebaceous epithelioma & 8 & 1.08 \\
\hline Myxoma & 5 & 0.68 \\
\hline Trichoepithelioma & 4 & 0.54 \\
\hline Sweat gland adenoma & 7 & 0.95 \\
\hline \multicolumn{3}{|l|}{ Malignant } \\
\hline Mast cell tumor & 124 & 16.78 \\
\hline Squamous cell carcinoma & 124 & 16.78 \\
\hline Histiocytoma & 61 & 8.25 \\
\hline Haemangiosarcoma & 59 & 7.98 \\
\hline Melanoma & 50 & 6.76 \\
\hline Trichoblastoma & 24 & 3.25 \\
\hline Liposarcoma & 20 & 2.71 \\
\hline Fibrosarcoma & 20 & 2.71 \\
\hline Sebaceous carcinoma & 16 & 2.16 \\
\hline Hepatoid gland carcinoma & 7 & 0.95 \\
\hline Sweat gland adenocarcinoma & 6 & 0.81 \\
\hline Haemangiopericitoma & 5 & 0.68 \\
\hline Myxosarcoma & 4 & 0.54 \\
\hline Other neoplasm & 34 & 4.61 \\
\hline Total & 739 & 100 \\
\hline
\end{tabular}


We evaluated 92 of the acquired slides, stained by haematoxylin and eosin, to screen for grades I, II, and III (Patnaik et al. 1984). To improve accuracy, the presence and intensity of oedema, necrosis, and haemorrhage were also assessed. When these features occupied $25 \%$ of the visual field (seen in a $\times 4$ field), they were classified as light; between $25 \%$ and $50 \%$, moderate; and more than 50\%, intense (Plate IV, Fig. 1). Eosinophil infiltrates were classified as light, moderate, and intense when seen in a subjective high-power field. The mitotic index was measured in 10 fields at the highest magnification with a zigzagging orientation, thus avoiding field repetition.

Skin cancer survey and location data were analysed using descriptive statistics and percentages. We examined the correlation between sex and breed and the occurrence of mast cell tumour, as well as the presence of necrosis, oedema, and haemorrhage using the chi-square test. A $P$ value $<0.05$ was considered significant, held in Action ${ }^{\circledR}$, 2.9 program.

\section{Results}

Between 2002 and 2012, a total of 5,800 diagnoses were carried out in the Animal Pathology Laboratory, Veterinary Hospital of the Federal University of Uberlândia. Among these, 1,749 (30.15\%) were canine neoplasms, with 739 (42.25\%) diagnosed as skin cancer, and 124 as mast cell tumours, corresponding to $16.8 \%$ of the total canine skin tumours (Table 1).

Among the dogs with mast cell tumours, 60 were female (49\%) and 62 were male (51\%), with 2 cases in which sex was not listed; however, there was no significant difference in the incidence of mast cell tumours between the sexes $(P=0.86)$.

In our study, the most frequent tumour site was the genital region (28.15\%), followed by the hind-limb (11.11\%) and the thorax (11.85\%); in 4 animals, the tumour location was not indicated (Table 2).

Table 2. Anatomical location of cutaneous mast cell tumours in dogs at the Federal University of Uberlândia (2002 to 2012).

\begin{tabular}{lcc}
\hline Location & Number & $(\%)$ \\
\hline Right flank & 2 & 1.48 \\
Tail & 4 & 2.96 \\
Inguinal & 5 & 3.70 \\
Fore-limb & 6 & 4.44 \\
Back & 8 & 5.93 \\
Head & 9 & 6.67 \\
Abdomen & 12 & 8.89 \\
Hind-limb & 15 & 11.11 \\
Thorax & 16 & 11.85 \\
Genital & 38 & 28.15 \\
Other & 20 & 14.81 \\
\hline
\end{tabular}

Animal breed was not mentioned in 9 chip files. Among those mentioned, 12 different breeds were seen over the 10-year study period. Mongrel dogs presented most frequently (30.43\%), followed by boxer (22.61\%) and pinscher (11.30\%) (Table 3 ).

The animals' ages ranged from 6 months to 16 years. Of the 92 slides analyzed for classification, $17(18.48 \%)$ were diagnosed as grade I, 57 (61.96\%) as grade II, and 18 $(19.56 \%)$ as grade III tumours. When relating the histological grade to injuries such as oedema, necrosis, and haemorrhage, grade I tumours had fewer lesions, with necrosis present in $23.5 \%$, and haemorrhage in $11.5 \%$. Grade III mast cell tumours showed both more necrosis $(50 \%)$ and more haemorrhaging $(55.5 \%)$, followed by oedema $(11 \%)$. There 
Table 3. Occurrence of cutaneous mast cell tumours according to breed at Federal University of Uberlândia (2002-2012).

\begin{tabular}{lcc}
\hline Breed & Number & $(\%)$ \\
\hline Cocker Spaniel & 1 & 0.87 \\
Doberman & 1 & 0.87 \\
Bichon Frisé & 2 & 1.74 \\
Fox Paulistinha & 2 & 1.74 \\
German Shepherd & 2 & 1.74 \\
Dachshund & 4 & 3.48 \\
Labrador & 5 & 4.35 \\
Poodle & 5 & 4.35 \\
Pit Bull & 9 & 7.83 \\
Fila Brasileiro & 10 & 8.70 \\
Pinscher & 13 & 11.30 \\
Boxer & 26 & 22.61 \\
Mongrel & 35 & 30.43 \\
\hline
\end{tabular}

was no significant relationship between findings of oedema, haemorrhage, and necrosis, and the histological classification $(P>0.05)$.

In the present study, eosinophil infiltrates were present in all grades. Moreover, the mitotic index was more related to tumour grade; grade III tumours had a greater number of mitotic cells compared to grades I and II.

\section{Discussion}

The high frequency of mast cell tumours $(16.68 \%)$ has also been reported by several authors, including Silva et al. (2011), who observed their occurrence at a frequency of $22 \%$, and Meirelles (2011), at 22.4\%.

About the sex of animals, Pinto et al. (2007) reported similar results with a group comprising $54 \%$ females and $46 \%$ males, as did Furlani et al. (2008) with a group with more male (28/49) than female dogs (21/49); both found no significant difference related to sex.

With respect to location, Natividade et al. (2014) reported the limbs as the primary site of involvement $(23.8 \%)$, followed by the scrotum (14.8\%). In our study, we found that Grade I tumours occurred more frequently in the limbs $(58 \%)$, whereas grade II tumours were most frequently located in the genitals $(32.35 \%)$. Grade III tumours occurred more frequently in the head (33.33\%). However, both Kiupel et al. (2005) and Sfiligoi et al. (2005) reported that mast cell tumours located in the scrotum and the preputial and inguinal regions were the most aggressive.

In the breeds, similar results were described in a study by Furlani et al. (2008), in which mongrel dogs comprised the largest sample (36.73\%), followed by boxer $(26.53 \%)$. The high percentage of mongrel dogs seen in our practice may be due to the larger number of animals presented at the Veterinary Hospital of the Federal University of Uberlândia.

The animals' ages (mean: 8.68 years), was similar to the mean age ( 7.5 years) reported by Pinto et al. (2007). Cockerell and Cooper (2002) reported that older animals are more exposed to carcinogens, the effects of which are cumulative. This is in line with the findings of this study, as $53.19 \%$ of the animals seen were older than 9 years.

Comparing the grade data with those of Patnaik et al. (1984), the percentages differed 
in relation to grade I and II cutaneous mast cell tumours; in their study, these tumours accounted for $36 \%$ and $43 \%$, respectively, of the total number of tumours. The findings for grade III tumours were similar, with an observed frequency of approximately $20 \%$.

Dias (2007) also noted necrosis and haemorrhaging in all 3 classifications. The presence of haemorrhage seemed to be related to the presence of heparin in the granules of mast cells, but this may be associated with the handling and degranulation of tumours during surgery (Thamm and Vail 2008).

Natividade et al. (2014) found no correlation between the number of eosinophils and the survival rate, but in their study, greater numbers of eosinophils were found in grade II tumours. The eosinophil infiltrates were present in all grades in Goldschmidt and Hendrick (2002) study.

Mitosis count has been cited by many authors as one of the factors for classification of cutaneous mast cell tumours (Patnaik 1984; Goldschmidt and Hendrick 2002; Romansik et al. 2007; Kiupel et al. 2011.). The study by Natividade et al. (2014) indicated that the mitosis count was the most reliable prognostic factor, apart from being easy and inexpensive to evaluate.

It has been concluded that cutaneous mast cell tumours are more prevalent in older animals, and show no sex preference. The most common histological grade is grade II, and the mitotic index should be considered the best tool to aid in mast cell tumour classification.

\section{References}

Childress MO 2015: Is 2 greater than 3? Making sense of a new 2-tiered grading system for cutaneous mast cell tumors in dogs. Adv Anim Med Surg 28: 1-3

Daleck CR, Rocha NS, Furlani JM, Cesar JRF 2009: Mast cell tumor. In: Daleck CR, Nardi AB, Rodaski S. Oncology in dogs and cats. Roca, pp 282-291

Furlani JM, Daleck CR, Vicenti FAM, Nardi AB, Pereira GT, Santana AE, Eurides D, Silva LAF 2008: Mastocitoma canino: Estudo restrospectivo. Ci Ani Bras 9: 242-250

Giorgi M 2012: Veterinary pharmacology: is it still pharmacology Cinderella? Clin Exp Pharmacol 2:103

Goldschmidt MH, Hendrick MJ 2002: Tumors of the skin and soft tissues. In: Meuten, DJ. Tumors in the domestic animals. $4^{\text {th }}$ edn. Iowa State Press, pp 45-118

Gross TL, Ihrke PJ, Walder EJ, Affolter VK 2005: Skin diseases of the dog and cat: Clinical and histopathologic diagnosis. $2^{\text {nd }}$ edn. Blackwell, Oxford, $932 \mathrm{p}$.

Kiupel M, Webster JD, Bailey KL, Best S, Delay J, Etrisac CJ, Fitzgerald SD, Gamble D, Ginn PE, Goldschmidt MH, Hendrick MJ, Howerth EW, Janovitz EB, Langohr I, Lenz SD, Lipscomb TP, Miller MA, Misdorp W, Moroff S, Mullaney TP, Neyens I, O’toole D, Ramos-vara J, Scase TJ, Schulman FY, Sledge D, Smedley RC, Smith K, Snyder PW, Southorn E, Stedman NL, Steficek BA, Stromberg PC, Valli VE, Weisbrode SE, Yager J, Heller J, Miller R 2011: Proposal of a 2-tier histologic grading system for canine cutaneous mast cell tumors to more accurately predict biological behavior. Vet Path 48: 147-155

Meirelles AEWB, Oliveira EC, Rodrigues BA, Costa GR, Sonne L, Tesser ES, Driemeier D 2010: Prevalence of cutaneous neoplasms in dogs from the metropolitan area of Porto Alegre, RS, Brazil: 1,017 cases (2002-2007). Pesqui Vet Bras 30: 968-973

Natividade FS, Castro MB, Silva AS, Galera PD 2014: Survival analyses and prognostic markers in canine cutaneos mast cell tumors. Pesqui Vet Bras 34: 874-884

Denicola D, Células Redondas 2009: In: Cowell RL, RD Tyler, JH Meinkhot, DB Denicola: Diagnóstico citológico e hematológico de cães e gatos. $3^{\text {rd }}$ edn. Medvet, São Paulo, pp 253-256

Patnaik AK, Ehler WJ, Macewen EG 1984: Canine cutaneous mast cell tumors: morphologic grading and survival time in 83 dogs. Vet Path 21: 469-474

Pinto JP, Teixeira LBC, Santos ARSJ 2007: Estudo histopatológico e histoquímico de mastocitomas na região de Espírito Santo do Pinhal. Rev Acad 5: 265-276

Thamm, DH, DM Vail 2008: Mast cell tumors. In: Withrow SJ, DM Vail: Small animal clinical oncology. $4^{\text {th }}$ edn. Saunders Elsevier, St. Louis, pp 402-424

Romansik EM, Reilly CM, Kass PH, Moore PF, London CA 2007: Mitotic Index is predictive for survival for canine cutaneous mast cell tumor. Vet Path 55: 335-341 
Plate IV

Costa M. C. et al.: Prevalence ... pp. 189-193

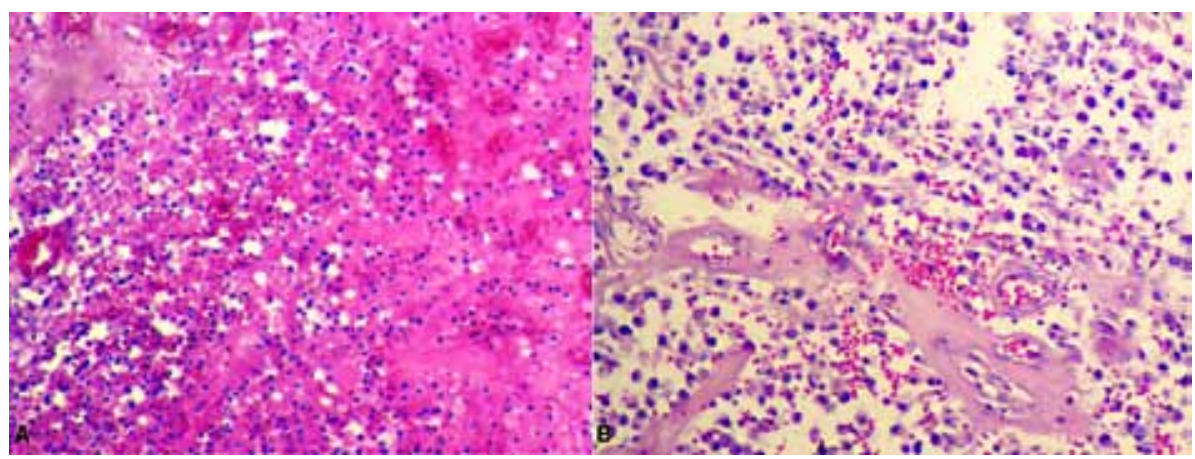

Fig. 1. Photomicrograph of a mastocytoma in the dog. A: Extensive area of necrosis, B: Area of haemorrhage interspersed within tumour cells. HE, $\times 10$ 